\title{
Utilization of arylaliphatic nitriles by haloalkaliphilic Halomonas nitrilicus sp. nov. isolated from soda soils
}

\author{
A. Chmura • A. A. Shapovalova $\cdot$ S. van Pelt $\cdot$ \\ F. van Rantwijk • T. P. Tourova • G. Muyzer • \\ D. Yu. Sorokin
}

Received: 28 July 2008 /Revised: 22 August 2008 / Accepted: 26 August 2008 / Published online: 16 September 2008

(C) The Author(s) 2008. This article is published with open access at Springerlink.com

\begin{abstract}
An enrichment culture from saline soda soils, using acetate as carbon and energy source and 2phenylpropionitrile as nitrogen source (PPN) at $\mathrm{pH} 10$, resulted in the isolation of strain ANL- $\alpha \mathrm{CH} 3$. The strain was identified as a representative of the genus Halomonas in the Gammaproteobacteria. The bacterium was capable of PPN utilization as a nitrogen source only, while phenylacetonitrile (PAN) served both as carbon, energy and nitrogen source. This capacity was not described previously for any other haloalkaliphilic bacteria. Apart from the nitriles mentioned above, resting cells of ANL$\alpha \mathrm{CH} 3$ also hydrolyzed mandelonitrile, benzonitrile, acrylonitrile, and phenylglycinonitrile, presumably using nitrilase pathway. Neither nitrile hydratase nor amidase activity was detected. The isolate showed a capacity to grow with benzoate and salicylate as carbon and energy source and demonstrated the ability to completely mineralize PAN. These clearly indicated a potential to catabolize aromatic com-
\end{abstract}

Electronic supplementary material The online version of this article (doi:10.1007/s00253-008-1685-x) contains supplementary material, which is available to authorized users.

A. Chmura $\cdot$ S. van Pelt $\cdot$ F. van Rantwijk

Biocatalysis \& Organic Chemistry, Department of Biotechnology,

Delft University of Technology,

Delft, The Netherlands

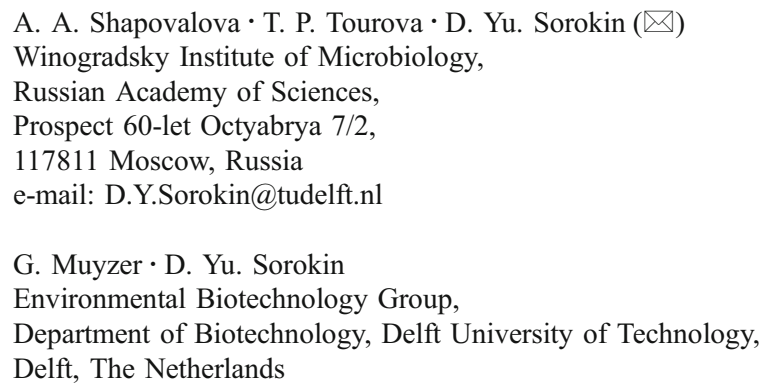

pounds. On the basis of unique phenotype and distinct phylogeny, strain ANL- $\alpha \mathrm{CH} 3$ is proposed as a novel species of the genus Halomonas-Halomonas nitrilicus sp. nov.

Keywords Nitriles $\cdot$ Phenylpropionitrile (PPN) · Phenylacetonitrile (PAN) · Haloalkaliphilic · Halomonas . Nitrilase

\section{Introduction}

Nitriles are mostly synthetic compounds containing a $\mathrm{C} \equiv \mathrm{N}$ functionality, although a few examples exist of naturally occurring nitriles formed by cyanogenic plants from cyanide (Vetter 2000) or during anaerobic degradation of amino acids by bacteria (Harper and Gibbs 1979). Nitrile compounds are widely used as intermediates and building blocks in organic synthesis. For example, the enzymatic hydrolysis of racemic nitriles into enantiomerically pure $\alpha$ substituted carboxylic acids is of great industrial interest. Nitriles can be used as precursors in the synthesis of $\alpha$ hydroxycarboxylic acids (Breuer et al. 2004) and amino acids, which are pharmaceutical intermediates and important resolution agents in organic resolution processes (Gröger 2001; Ravichandran et al. 1998). Most nitriles are toxic and difficult to degrade. Nevertheless, the potential for enzymatic hydrolysis of the nitrile bond is widely spread among bacteria and fungi (Banerjee et al. 2002). Two different enzymatic systems are known to convert nitriles into the corresponding carboxylic acids. The metalloenzyme nitrile hydratase catalyzes the hydration of a wide range of aliphatic, arylaliphatic, and aromatic nitriles into the corresponding amides, which are then further converted into carboxylic acids and ammonium by amidases (Kobayashi and Shimizu 1998). Nitrilases hydrolyze nitriles, mostly 
aromatic, directly into acids and ammonium in a single step (Kobayashi and Shimizu 2000). The microorganisms possessing these enzymes are valuable biocatalysts and can be used either in (enantioselective) organic synthesis or in environmental biotechnology (Layh et al. 1997; Bunch 1998; Håkansson et al. 2005).

Until now, all known nitrile-degrading microorganisms included only neutrophilic species, i.e., growing optimally at neutral $\mathrm{pH}$ values. However, a recent survey of naturally occurring haloalkaline habitats, such as soda lakes and soda soils, demonstrated the possibility of biodegradation of simple aliphatic nitriles at extremely alkaline conditions. The compounds, such as aceto-, propio-, butyro-, iso-butyro-, and valero-nitriles, were utilized as carbon, energy, and nitrogen source by a novel haloalkaliphilic Gammaproteobacterium, an actinobacterium and bacilli (Sorokin et al. 2007a, b). The potential for enzymatic nitrile hydrolysis at highly alkaline conditions might have certain advantages, particularly when cyanide is involved in the reaction process. For example, a well-known chemical Strecker reaction could be coupled with enzymatic $\alpha$-aminonitrile hydrolysis to (enantioselectively) produce $\alpha$-aminoamides and/or $\alpha$-aminoacids (Duthaler 1994).

In this paper, the biodegradation of a variety of arylaliphatic nitriles is demonstrated under extremely haloalkaline conditions by a novel species of the genus Halomonas isolated from soda soils. The capacity to hydrolyze nitrile compounds has never been demonstrated previously for this metabolically diverse group of halo (alkali)philic Gammaproteobacteria.

\section{Materials and methods}

\section{Source of inoculum}

A mixed sediment sample from Kulunda Steppe (southwestern Siberia, Altai, Russia) soda lakes and a mix sample from soda solonchak soils (Kulunda Steppe and northeastern Mongolia) were used as the inoculum for the enrichments. The $\mathrm{pH}$ and salinity of the lake brines were within the range of 9.5-11.05 and 50-400 $\mathrm{g} \mathrm{L}^{-1}$, respectively. The $\mathrm{pH}$ of water extract from the solonchak soil samples varied from 9.5 to 10.8 and the total salt content-from 30 to $200 \mathrm{~g} \mathrm{~kg}^{-1}$.

Medium composition and growth conditions

A mineral medium based on sodium carbonate buffer $\left(\mathrm{pH} 10,0.6 \mathrm{M}\right.$ total $\mathrm{Na}^{+}$) was used for enrichments and pure culture study $\left(\mathrm{g} \mathrm{L}^{-1}\right): \mathrm{Na}_{2} \mathrm{CO}_{3}, 22 ; \mathrm{NaHCO}_{3}, 8 ; \mathrm{NaCl}$, 6; $\mathrm{K}_{2} \mathrm{HPO}_{4}, 0.5$. The $\mathrm{pH}$ of this medium was stable even after prolonged incubation. After sterilization, the medium was supplemented with $1 \mathrm{~mL}$ trace metal solution $\mathrm{L}^{-1}$ (Pfennig and Lippert 1966), $1 \mathrm{mM} \mathrm{MgSO}_{4}$, and $0.1 \mathrm{mg} \mathrm{L}^{-1}$ of filter-sterilized vitamin $\mathrm{B}_{12}$. The enrichment was performed in $100-\mathrm{mL}$ serum bottles closed with grey rubber septa (to prevent loss of substrate) containing $20 \mathrm{~mL}$ medium and $1 \mathrm{~cm}^{3}$ sediment or soil mixture. Nitriles were added directly from the pure source into the medium (2$4 \mathrm{mM}$ ) and the bottles were immediately sealed to prevent the substrate loss. It is necessary to stress that the nitriles used in the growth experiments and $\mathrm{pH}$ profiling (phenylpropionitrile (PPN) and phenylacetonitrile (PAN)) were chemically stable up to $\mathrm{pH} 11$ as was demonstrated in abiotic controls. In case of solid medium (solidifying agent was Noble agar, Difco), PPN was added after cooling the medium down to $50{ }^{\circ} \mathrm{C}$ to prevent excessive loss of substrate and the plates were incubated in closed jars for 30 days. Liquid cultures were incubated on a rotary shaker at $150 \mathrm{rpm}$ and $28{ }^{\circ} \mathrm{C}$ and were periodically checked for growth and ammonia formation. The positive cultures were serially diluted and the culture obtained from a maximal positive dilution was plated onto the solid medium. Separate colonies were placed into liquid medium with PPN and acetate in 30-mL serum bottles closed with rubber septa and with $5 \mathrm{~mL}$ liquid. Positive cultures were plated again to check for the purity.

Growth experiments with pure cultures were performed in $1 \mathrm{~L}$ closed serum bottles with $100 \mathrm{~mL}$ liquid on a rotary shaker at $150 \mathrm{rpm}$ and $30^{\circ} \mathrm{C}$. Substrates were used at $2-$ $20 \mathrm{mM}$ concentration. Growth was monitored by optical density and the degradation of nitriles was followed by ammonium production, disappearance of substrate, and formation of intermediates. The $\mathrm{pH}$ profiling of growth was performed in the medium containing $0.6 \mathrm{M}$ total $\mathrm{Na}^{+}$ either as $\mathrm{NaCl}(\mathrm{pH} 6.5-8.0)$ or $\mathrm{NaHCO}_{3} / \mathrm{Na}_{2} \mathrm{CO}_{3}(\mathrm{pH} 8.5-$ 11.0). The salt dependence of growth was investigated in a range of sodium carbonate-based media containing 0.14.0 $\mathrm{M}$ total $\mathrm{Na}^{+}$at $\mathrm{pH} 10$. The substrate utilization spectrum was investigated in standard medium at $\mathrm{pH} 10$ using $\mathrm{NH}_{4} \mathrm{Cl}$ $(4 \mathrm{mM})$ as the nitrogen source.

Experiments with washed cells and cell-free extract

To determine the spectrum of nitrile degradation and the influence of $\mathrm{pH}$ and salt concentration on the nitrilase activity, the cells grown at $\mathrm{pH} 10$ and $0.6 \mathrm{M} \mathrm{Na}^{+}$with $\mathrm{PPN}+$ acetate or with PAN alone were harvested, washed and resuspended in $0.5 \mathrm{M}$ sodium carbonate buffer, $\mathrm{pH} 9$ at a cell density of $20-25 \mathrm{mg}$ protein $\mathrm{mL}^{-1}$. Routine activity check was performed by measuring ammonia formation over time at $\mathrm{pH} 10$ and $0.6 \mathrm{M}$ total $\mathrm{Na}^{+}$. Activity and time course measurements with the determination of nitrile consumption and amide and acid 
production were carried out in 2-mL Eppendorf tubes shaken on a ThermoTWISTER comfort shaker (QUANTIFOIL Instruments) at a cell density of $0.1-0.6 \mathrm{mg}$ protein $\mathrm{mL}^{-1}$ in either $20 \mathrm{mM}$ citrate buffer $\mathrm{pH} 5.5,0.1 \mathrm{M}$ phosphate buffer $\mathrm{pH} 7$ or $20 \mathrm{mM}$ carbonate buffer $\mathrm{pH} 8.4$ and at 5 or $25^{\circ} \mathrm{C}$. Reactions were initiated by the addition of nitriles $(10 \mathrm{mM})$ in the presence of $4 \mathrm{mM}$ internal standard (veratrol). The final reaction volume was $1.0 \mathrm{~mL}$. Regular samples were taken at regular time intervals and quenched in $\mathrm{HCl}$-acidified mobile phase solution. After centrifugation of the denatured protein, the supernatant was injected directly on the high performance liquid chromatograph (HPLC). Samples for straight-phase HPLC measurements were extracted with ethyl acetate and then dried over $\mathrm{Na}_{2} \mathrm{SO}_{4}$ before injection.

For the fed-batch experiments, $150 \mu \mathrm{L}$ of Halomonas sp. cell suspension $(0.87 \mathrm{mg})$ was washed and resuspended in $0.1 \mathrm{M}$ phosphate buffer $\mathrm{pH} 7$ to a final volume of $1 \mathrm{~mL}$ in a 1.5-mL Eppendorf tube. Also, $12 \mu \mathrm{L}$ of pure PAN ( $89 \mathrm{mM}$ ) or $16 \mu \mathrm{L}(100 \mathrm{mM})$ rac-phenylglycinonitrile was added to start the reaction. Additional substrate was added only after full conversion was achieved. The reaction was carried out at $25{ }^{\circ} \mathrm{C}$ and samples were taken periodically.

In order to test the stability of the whole cell biocatalyst, resting cells were suspended in sodium carbonate buffer of pH $10\left(20-25 \mathrm{mg}\right.$ protein $\left.\mathrm{mL}^{-1}\right)$ and subsequently stored on ice. During time the activity of the cells was determined by incubating a sample of the cell suspension in $20 \mathrm{mM}$ citrate buffer of pH 5.5 with $10 \mathrm{mM}$ PAN and $2.5 \mathrm{mM}$ of internal standard (veratrol) at $25^{\circ} \mathrm{C}$.

Cell-free extract was obtained either by using an IKS Lab Equipment Constant Cell Disruption System at 2 kbar at room temperature or by osmotic shock after lysozyme treatment $\left(1 \mathrm{mg} \mathrm{mL}^{-1}\right)$. The cell debris and unbroken cells were removed by centrifugation at $30,000 \times g$ for $5 \mathrm{~min}$.

\section{Analytical procedures}

Nitrile, amide, and carboxylic acid concentrations during the reaction were determined by HPLC. The conversions of mandelonitrile, PPN, benzonitrile, and PAN were followed on an Alliance Waters 2695 Separation Module equipped with a Waters 2487 Dual $\lambda$ UV Absorbance Detector using a $4.6 \times 50 \mathrm{~mm}$ Merck Chromolith SpeedROD RP-18e reversed-phase column and $\mathrm{H}_{2} \mathrm{O}: \mathrm{ACN}(90: 10)+0.1 \%(v / v)$ trifluoroacetic acid (TFA) as eluent $\left(1 \mathrm{~mL} \mathrm{~min}{ }^{-1}\right)$. Wavelength of the detector was set at $215 \mathrm{~nm}$.

The enantiomeric purity of the hydrolysis products of $r a c$-mandelonitrile and $r a c$-PPN was determined on an HPLC system equipped with a Waters 515 pump and a Waters 486 Tunable Absorbance Detector, which was set at $215 \mathrm{~nm}$. Separation was achieved using a straight-phase $4.6 \times 250 \mathrm{~mm}$ Chiralpak AD-H column with hexane: isopropanol 80:20 (rac-mandelonitrile) and 90:10 (racPPN $)+0.1 \%(v / v)$ TFA as eluents $\left(0.5 \mathrm{~mL} \min ^{-1}\right)$. The conversion of rac-phenylglycinonitrile and the enantiopurities of the corresponding acids were determined using the same HPLC module as above. Separation was obtained using a Daicel Crownpak $\mathrm{CR}(+)$ column and $\mathrm{H}_{2} \mathrm{O}+0.1 \%(v / v) \mathrm{HClO}_{4}$ as eluent $\left(0.5 \mathrm{~mL} \mathrm{~min}^{-1}\right)$. Conversions of acrylonitrile and 3-cyanopyridine were followed on an HPLC system with a Waters 590 programmable HPLC pump and a Shimadzu SPD-10A VP UV-VIS detector. Separation was achieved using three $4.6 \times 50 \mathrm{~mm}$ Merck Chromolith ${ }^{\mathrm{TM}}$ SpeedROD RP-18e columns in series for acrylonitrile and a single column for 3-cyanopyridine. Water $+0.1 \%(v / v)$ TFA (acrylonitrile) or acetic acid (3-cyanopyridine) was used as eluent. The UV detector was set at $210 \mathrm{~nm}$.

Ammonium and cell protein concentrations were detected spectrophotometrically according to Weatherburn (1967) and Lowry et al. (1951).

The isolation of the DNA and subsequent determination of the $\mathrm{G}+\mathrm{C}$ content were performed by the thermal denaturation/reassociation technique (Marmur 1961; Marmur and Doty 1962). Genomic DNA for phylogenetic analysis was extracted from the cells using the UltraClean Soil DNA Extraction Kit (MolBio Laboratories, USA) following the manufacturer's instructions. The 16S rRNA genes were amplified using general bacterial primers. The PCR products were purified from lowmelting agarose using the Wizard PCR-Prep kit (Promega, USA) according to the manufacturer's instructions. Sequencing was performed using the Big Dye Terminator v.3.1 sequencing reaction kit on an ABI 3730 DNA automatic sequencer (Applied Biosystems, Inc., USA). The sequences were first compared with those stored in GenBank using the BLAST algorithm. The sequences were aligned with those from the GenBank using CLUSTALW. Phylogenetic trees were constructed with four different algorithms using the TREECONW program package (van de Peer and de Wachter 1994).

\section{Results}

Enrichment and isolation of a PPN-utilizing haloalkaliphile

No growth or ammonia formation was observed upon incubation of soda soil and soda lake sediments at $\mathrm{pH} 10$ with PPN as the only substrate. However, when it was used as a nitrogen source in the presence of acetate as carbon and energy source, a positive enrichment culture was obtained from soda soils. The culture was dominated 
by fat nonmotile rods filled with refractive inclusions (Supplementary Fig. 1). A pure culture, designated strain ANL- $\alpha \mathrm{CH} 3$, was isolated from a single colony and proved to be able to utilize PPN as nitrogen source. Phylogenetic analysis (Fig. 1) placed the isolate into the genus Halomonas in the Gammaproteobacteria with haloalkaliphilic species $H$. campisalis and $H$. campaniensis as the closest relatives ( $97 \%$ sequence similarity). The genus Halomonas accommodates a wide range of species characterized by high halo- and alkali-tolerance but the ability to utilize nitriles has never been demonstrated in this physiologically versatile group.

Growth of strain ANL- $\alpha \mathrm{CH} 3$ with arylaliphatic nitriles at $\mathrm{pH} 10$

The bacterium was not able to grow with PPN alone. When the latter was supplied at concentrations 0.5$4 \mathrm{mM}$ in presence of $20 \mathrm{mM}$ acetate, the growth occurred with the maximum specific growth rate of

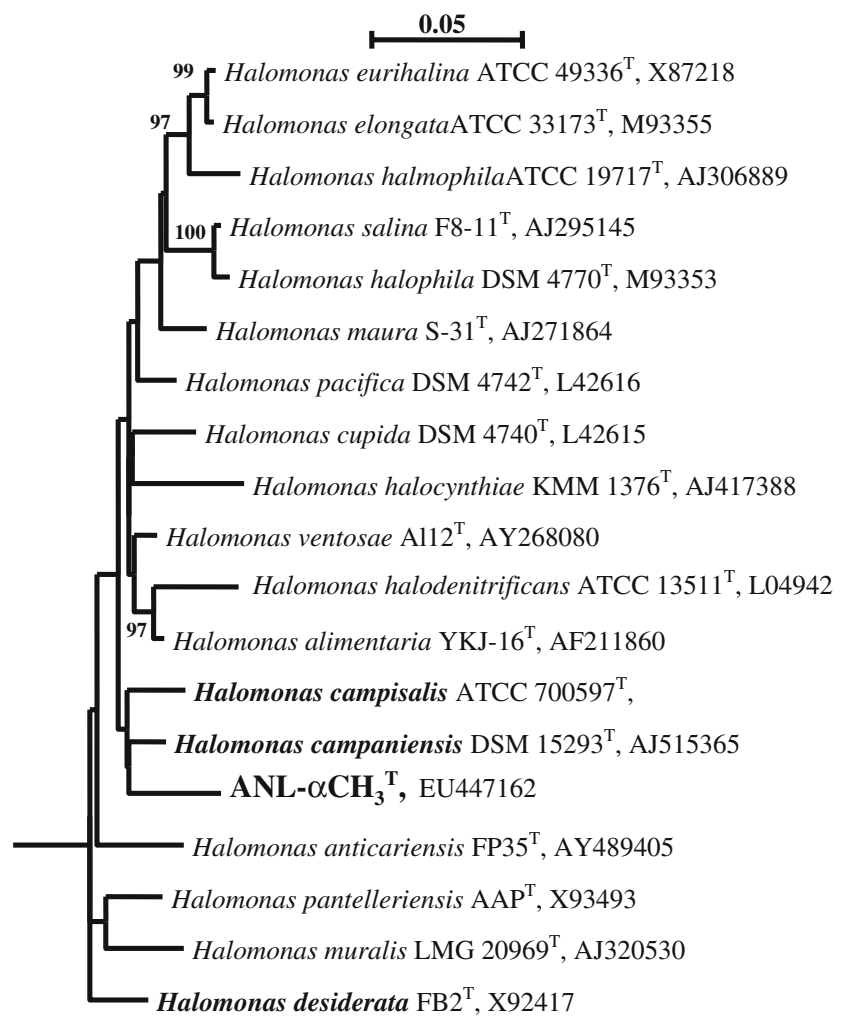

Fig. 1 Phylogenetic tree based on 16S rRNA gene sequencing, showing the position of strain ANL- $\alpha \mathrm{CH} 3$ within the genus Halomonas. Tree topography and evolutionary distances are given by the neighbor-joining method with Jukes \& Cantor distances. Numbers at the nodes indicate the percentage of bootstrap values for the clade in 1,000 replications. Only values above $90 \%$ are shown. Haloalkaliphilic species are shown in bold
$0.12 \mathrm{~h}^{-1}$, usually after a $20-30-\mathrm{h}$ lag phase. Ammonium was not detected in the culture supernatant.

In contrast, PAN supported the growth without an additional carbon and energy source and the final growth yield was proportional to the initial PAN concentration up to $5 \mathrm{mM}$. Higher PAN concentrations inhibited growth of the bacterium. During the growth, PAN was rapidly consumed releasing nearly stoichiometric amounts of ammonia during the early logarithmic growth phase with only a limited intermediate accumulation of phenylacetic acid (PAA) (Fig. 2). The biomass production continued after complete PAN disappearance, signifying the formation of an essential intermediate. HPLC analysis, however, did not show any formation of phenylacetamide. High growth yield (biomass on $2 \mathrm{mM}$ PAN was equivalent to the yield on $10 \mathrm{mM}$ acetate) indicated complete utilization of PAN. The latter indicates an ability to utilize the aromatic ring, which is not an ordinary property of the genus Halomonas. The capacity of the bacterium to metabolize the aromatic ring was confirmed in growth experiments with benzoic and salicylic acids. The culture, pre-grown on PAN, started to grow with benzoate (up to $5 \mathrm{mM}$ ) and salicylate (up to $3 \mathrm{mM}$ ) after a 1-day lag phase. The growth resulted in the accumulation of a brownish soluble compound in both cases, which is in contrast to the PAN culture (Supplementary Fig. 2). The same effect was observed in sterile control alkaline medium when it was incubated with catechol. This suggests that the oxidation of benzoic and salicylic acids was going through a diquinol with partial spontaneous side oxidation of the latter at highly alkaline conditions. In contrast, utilization of PAN either did not result in substantial accumulation of autooxidizable intermediate(s) or proceeded through a different ring hydroxylation pathway. Phenol (1-2 mM)

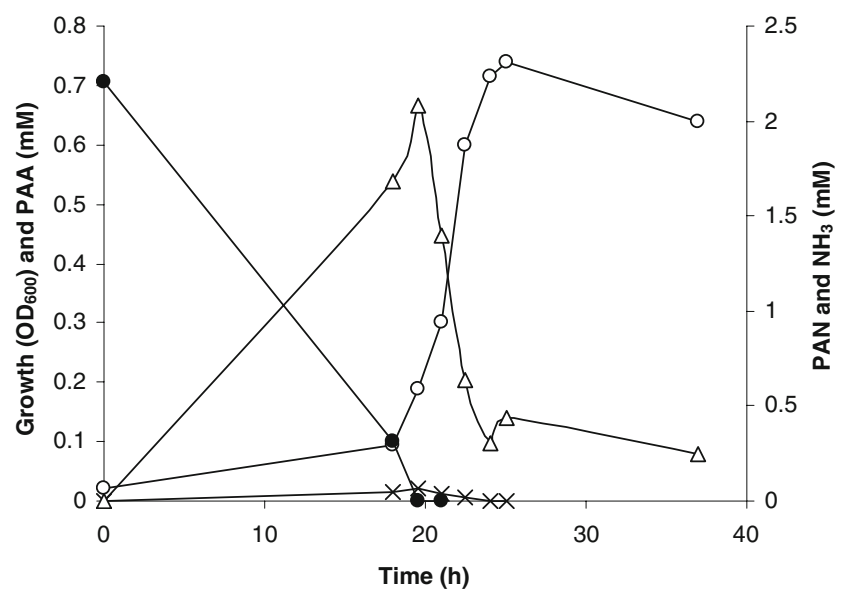

Fig. 2 Growth dynamic of strain ANL- $\alpha \mathrm{CH} 3$ at $\mathrm{pH} 10$ with PAN as substrate. Open circles, biomass growth; triangles, ammonia formation; closed circles, PAN; crosses, phenylacetic acid (PAA) 
did not support growth of the novel bacterium, in contrast to $H$. campisalis.

Influence of $\mathrm{pH}$ on growth and nitrile hydrolysis

One of the main purposes of this work was to investigate a possibility of bio-conversion of arylaliphatic nitriles at extremely haloalkaline conditions. The $\mathrm{pH}$ profile for growth with PPN as the nitrogen source indicated a moderate alkaliphilic nature of the novel isolate (Fig. 3). On the other hand, resting washed cells of strain ANL$\alpha \mathrm{CH} 3$, pre-grown at $\mathrm{pH} 10$ with $\mathrm{PPN}$ and acetate, were able to actively hydrolyze nitriles within a much broader $\mathrm{pH}$ range from $\mathrm{pH} 5$ and at least up to $\mathrm{pH} 11$ with an optimum within the alkaline region (Fig. 3).

\section{Catalytic properties of Halomonas ANL- $\alpha \mathrm{CH} 3$}

Resting cell incubation tests with 2-phenylpropionamide, phenylacetamide, and rac-mandelamide did not result in acid formation even after $20 \mathrm{~h}$ of incubation. As was mentioned before, intermediate amide formation was also not observed during growth of the organism on PAN and
PPN. These observations indicate that ANL- $\alpha \mathrm{CH}_{3}$ degrades aromatic nitriles through the nitrilase pathway.

Nine different aliphatic and aromatic nitriles with straight and branched side chains were tested for conversion by using washed cells of strain ANL- $\alpha \mathrm{CH}_{3}$ pre-grown with PPN. The influence of different $\alpha$ substitutes (and enantiomers) on the reaction rate was also investigated (Table 1). As expected, the highest conversion rate was obtained with PAN, since it was utilized as carbon source. The nitrilase proved to be strongly $(R)$-selective. The experimental results with $(R)$ and $(S)$-mandelonitrile showed that the $(R)$-enantiomer is converted 20 times faster than the $(S)$-one (Fig. 4a). The strong but not absolute $(R)$-selectivity of ANL- $\alpha \mathrm{CH} 3$ was confirmed in kinetic resolution tests with other chiral nitriles, such as phenylglycinonitrile and 2-phenylpropionitrile (Fig. 4b and c). An interesting example of application of the nitrilase from ANL- $\alpha \mathrm{CH} 3$ strain is in situ dynamic kinetic resolution of $(R, S)$-mandelonitrile (Fig. 4d). In the process, the unwanted enantiomer was racemized via the nitrile decomposition and chemical hydrocyanation pathway according to the following scheme:

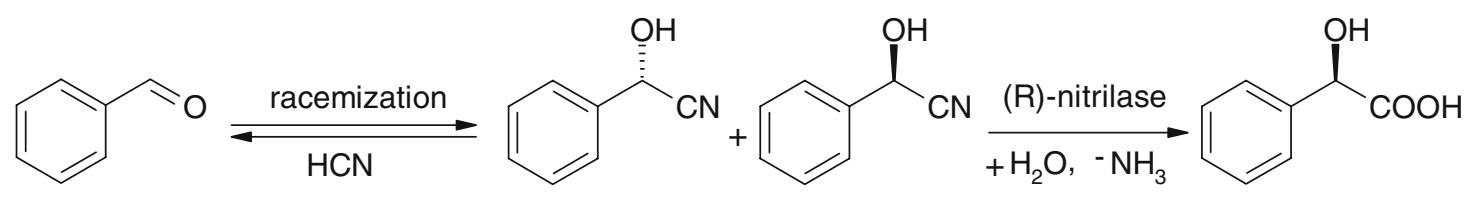

The fast racemization assured a constant supply of the desired $(R)$-enantiomer of cyanohydrin, which was then fully converted by the nitrilase into $(R)$-mandelic ( $+95 \%$ ee) acid in $2 \mathrm{~h}$.

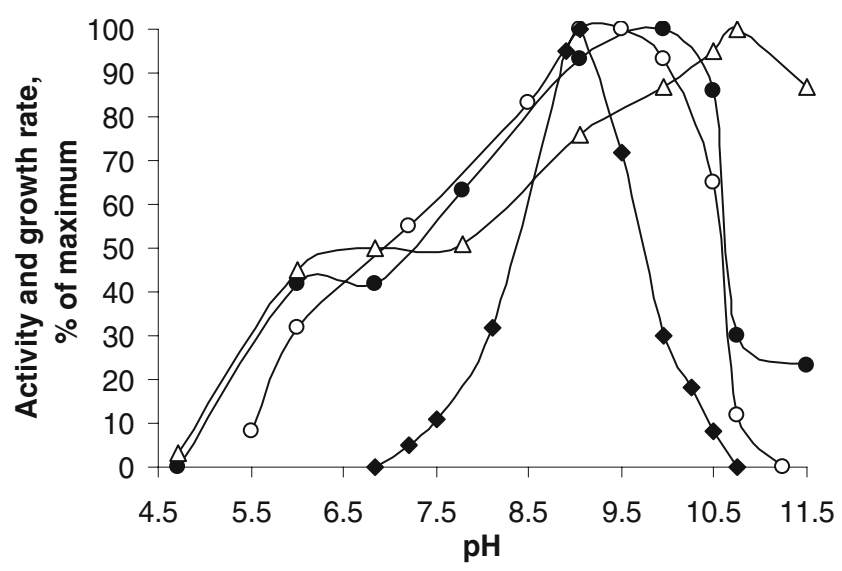

Fig. 3 Influence of $\mathrm{pH}$ on growth of strain ANL- $\alpha \mathrm{CH} 3$ with PPN and acetate (diamonds) and on activity of nitrile hydrolysis (ammonia formation rate) by washed cells (PPN, closed circles; PAN, open circles; acrylonitrile, triangles)

A fed-batch experiment with PAN demonstrated that the Halomonas cells could convert $0.8 \mathrm{M}$ of the nitrile into crystalline PAA. The substrate was added in nine equal portions. Every subsequent portion reached full conversion slower than the previous one (first portion was converted in $<3.5 \mathrm{~h}$ and the eighth portion was fully converted in $\sim 27 \mathrm{~h}$ ). The cells eventually stopped working after converting a part of the last, ninth, portion. In a similar experiment with phenylglycinonitrile, at least $0.2 \mathrm{M}$ was converted into the corresponding rac-phenylglycine (Fig. 4a) and the cells would have probably converted more since there were no signs of inhibition by the final product.

A 3-month storage test on ice demonstrated that the cells, when resuspended in sodium carbonate buffer of $\mathrm{pH}$ 10 , are highly stable. No change in activity was observed during this time of storage.

During cell disruption experiments, the cell-free preparations obtained by using osmotic shock resulted in better activity retention compared to disruption using rapid decompression. Moreover, $85 \%$ of the activity was recovered in the extract when using anaerobic conditions, and $31 \%$ when using aerobic conditions during the osmotic 
Table 1 Nitrilase activity (carboxylic acid formation from nitrile) in resting cells of strain ANL- $\alpha \mathrm{CH} 3$ (grown with PAN at pH 10)

\begin{tabular}{|c|c|c|c|}
\hline Nitrile compound & Structure of nitrile & $\begin{array}{c}\text { Nitrilase activity, } \\
\text { nmol (mg protein } \\
\text { min) }^{-1}\end{array}$ & $\begin{array}{l}\text { pH of the } \\
\text { test }\end{array}$ \\
\hline PAN & & 770 & 7.0 \\
\hline PPN & & 50 & 7.0 \\
\hline \multirow{3}{*}{$(R, S)$-mandelonitrile } & & 180 & 5.5 \\
\hline & & 26 & $5.5\left(5^{\circ} \mathrm{C}\right)$ \\
\hline & & 180 & 7.0 \\
\hline$(R)$-mandelonitrile & & 2.5 & $5.5\left(5^{\circ} \mathrm{C}\right)$ \\
\hline (S)-mandelonitrile & & 50 & $5.5\left(5^{\circ} \mathrm{C}\right)$ \\
\hline Phenylglycinonitrile & & 460 & 8.4 \\
\hline Benzonitrile & & 0.11 & 7.0 \\
\hline Acrylonitrile & & 210 & 7.0 \\
\hline Nicotinonitrile & & 1.7 & 7.0 \\
\hline
\end{tabular}

shock. In contrast, rapid decompression resulted in only $8 \%$ activity recovery.

\section{Discussion}

This is the first report in literature of a haloalkaliphilic bacterium capable of utilizing arylaliphatic nitriles. The bacterium can hydrolyze several arylaliphatic nitriles at a $\mathrm{pH}$ as high as $10-10.5$ and salt concentrations of up to $3.5 \mathrm{M}$ total $\mathrm{Na}^{+}$. Most interesting is the capacity of the novel Halomonas isolate to grow exclusively with PAN. In fact, the potential to use phenol and its derivative carbonic acids at haloalkaline conditions has so far been shown only for a few Halomonas strains and only one of them is haloalkaliphilic: the immediate relative of strain ANL- $\alpha \mathrm{CH} 3$ H. campisalis (Alva and Peyton 2003). But, in contrast to the latter, our isolate did not utilize phenol (1-5 mM). The exact pathway of the PAN and PPN degradation in the novel strain needs special investigation. 
Fig. 4 Biocatalytic properties of washed cells of strain ANL$\alpha \mathrm{CH} 3$. a Hydrolysis of rac-phenylglycinonitrile with Halomonas sp. resting cells at $\mathrm{pH} 8.4$ and $25{ }^{\circ} \mathrm{C}$ (diamonds, 2 phenylglycinonitrile; squares, phenylglycine; circles, ee $(R)$ phenylglycine). b Hydrolysis of rac-mandelonitrile at $\mathrm{pH} 5.5$ and $5{ }^{\circ} \mathrm{C}$ (triangles, benzaldehyde; diamonds, mandelic acid; squares, mandelonitrile; circles, ee $(R)$-mandelic acid).

c Hydrolysis of rac-2-

phenylpropionitrile at $\mathrm{pH} 7$ and $25{ }^{\circ} \mathrm{C}$ (diamonds, 2-

phenylpropionitrile; squares, 2phenylpropionic acid; circles, ee $(R)$-phenylpropionic acid). d One pot chemo-enzymatic dynamic kinetic resolution synthesis of $(R)$-mandelic acid at $\mathrm{pH} 7$ (squares, rac-mandelonitrile; diamonds, mandelic acid; triangles, benzaldehyde; circles, ee (R)-mandelic acid) a

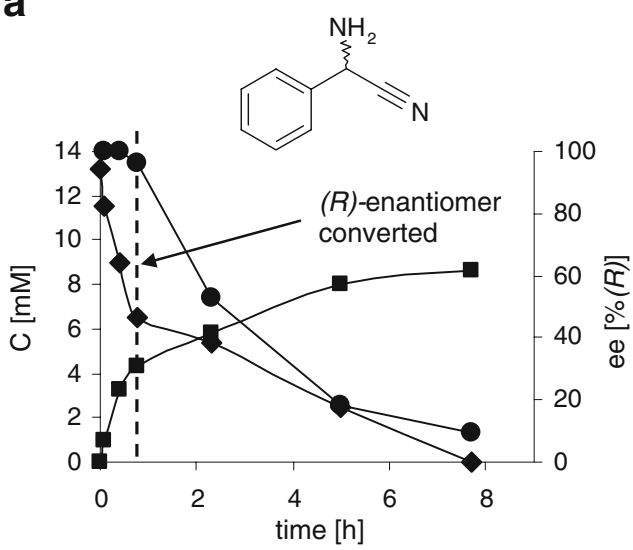

b

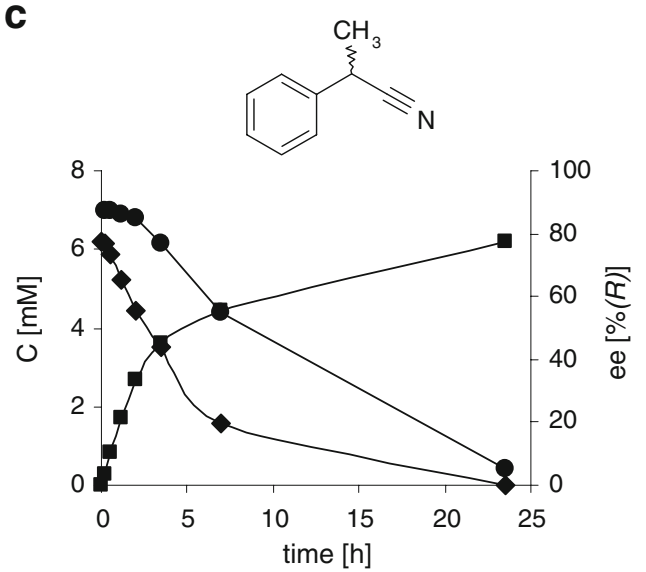

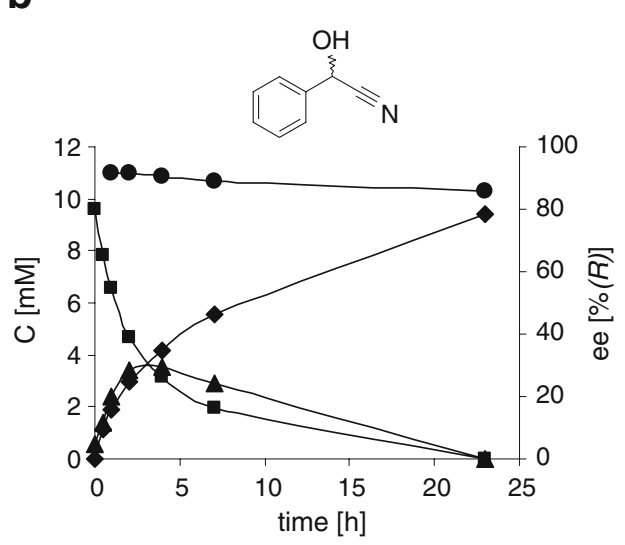

d

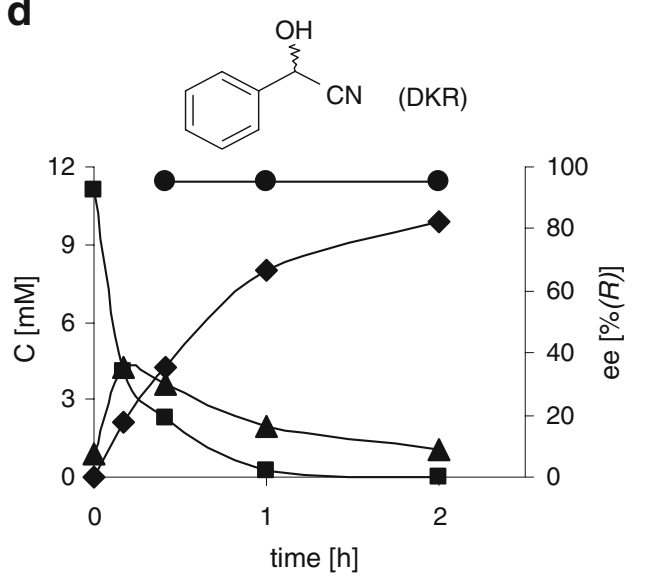

The ability of the isolate to grow with benzoic and salicylic acids suggests a potential for the complete aromatic ring degradation. Absence of PAA accumulation in the culture supernatant during growth on PAN and a certain disbalance between PAN hydrolysis and PAA accumulation by washed cells indicated rapid utilization of the acid. However, while it is easy to explain for the growing culture, the reason for PAA deficiency in washed cell experiments is not clear. Our first hypothesis was that the washed cells could have rapidly oxidized the PAA formed from PAN. However, special anoxic test showed the same disbalance, while anoxic incubation with PAA demonstrated no consumption. Perhaps, the cells might contain some of the PAA formed during intracellular PAN hydrolysis. While PAN is clearly a xenobiotic, PAA is a natural compound with plant hormone activity which occurrence is related to phenylalanine metabolism. Many bacteria can utilize this compound by activation with CoA followed by ring hydroxylation (Navarro-Llorens et al. 2008). In any case, the exact mechanism of PAA utilization in alkaliphilic Halomonas strain needs further detailed analysis.

Assuming its $R$-enantioselectivity, the nitrilase from ANL- $\alpha \mathrm{CH} 3$ might be useful in the (dynamic) kinetic resolution of phenylglycinonitrile (see Fig. 4). The hydrolysis product, $(R)$-phenylglycine, is an intermediate in the synthesis of $\beta$-lactam antibiotics (Mueller and Huebner 2003).

The differences in anaerobic and aerobic cell disruption experiments revealed a negative influence of oxygen on the enzyme. The activity loss, caused by exposure to oxygen, might be caused by oxidation of the catalytic cysteine present in the ANL- $\alpha \mathrm{CH}_{3}$ nitrilase. This catalytic cysteine is present in all known nitrilases (Mateo et al. 2006). The stability of the free enzyme is an important issue. The nitrilase is unstable outside of the cell environment. Unlike the whole cells, cell-free extracts from both disruption experiments quickly (after several days) lost most of their initial activity. The activity loss is not caused by proteases and it can be partially improved by adding glycerol to the storage medium.

In conclusion, the data presented indicate the possibility of biodegradation and utilization of a broad range of arylaliphatic nitriles at a $\mathrm{pH}$ range between 5.5 and 11 by a novel haloalkaliphilic isolate, strain ANL- $\alpha \mathrm{CH} 3$, presumably through nitrilase system. Assuming unique phenotypic properties and distinct phylogeny, strain ANL- $\alpha \mathrm{CH} 3$ is proposed as a new species Halomonas nitrilicus sp. nov. 
Description of Halomonas nitrilicus sp. nov.

(ni.tri'li.cus N.L. n. nitrilum nitrile, nitrile group; N.L. adj. nitrilicus nitrile-utilizing)

Nonmotile, Gram-negative rods, $0.5 \times 1.5-3 \mu \mathrm{m}$. Utilizes phenylpropionitrile as nitrogen source and phenylacetonitrile as carbon, energy, and nitrogen source. Able to hydrolyze a range of arylaliphatic and aliphatic nitriles using the nitrilase system. Also utilizes as carbon and energy source the following substrates: acetate, propionate, butyrate, pyruvate, fumarate, succinate, citrate, malate, lactate, ethanol, glucose, maltose, sucrose, cellobiose, galactose, raffinose, trehalose, glycerol, mannitol, sorbitol, xylose, and glycogen. Degrades and utilizes as sole growth substrates benzoate and salicylate. Cannot grow anaerobically with nitrate, nitrite, or $\mathrm{N}_{2} \mathrm{O}$. Moderately alkaliphilic with a $\mathrm{pH}$ range for growth between 7.5 and 10.5 with an optimum at $\mathrm{pH} 9$ and extremely salt tolerant, growing at salt concentrations from 0.1 to $3.5 \mathrm{M}$ total $\mathrm{Na}^{+}$with an optimum at $0.3-0.5 \mathrm{M}$. Optimum growth temperature is $32{ }^{\circ} \mathrm{C}$. The $\mathrm{G}+\mathrm{C}$ content in the genomic DNA is $62.5 \mathrm{~mol} \%$ (Tm). The type strain is ANL- $\alpha \mathrm{CH}^{\mathrm{T}}$ $\left(\mathrm{NCCB} 100121^{\mathrm{T}}=\mathrm{UNIQEM} \mathrm{U} 241^{\mathrm{T}}\right)$ is isolated from soda soils in south-eastern Siberia. The nearest cultured relative is Halomonas campisalis. The GenBank accession number of the 16S-rRNA gene sequence of the type strain is EU447162.

Acknowledgements This work was supported by NWO-RFBR (47.011.2004.010), NWO under CERC3, RFBR (07-04-00153), and by the program on Molecular and Cell Biology RAS.

Open Access This article is distributed under the terms of the Creative Commons Attribution Noncommercial License which permits any noncommercial use, distribution, and reproduction in any medium, provided the original author(s) and source are credited.

\section{References}

Alva V, Peyton BM (2003) Phenol and catechol biodegradation by the haloalkaliphile Halomonas campisalis: influence of $\mathrm{pH}$ and salinity. Environ Sci Technol 37:4397-4402

Banerjee A, Sharma R, Banerjee UC (2002) The nitrile-degrading enzymes: current status and future prospects. Appl Microbiol Biotechnol 60:33-44

Breuer M, Ditrich K, Habicher T, Hauer B, Kesseler M, Stürmer R, Zelinski T (2004) Industrial methods for the production of optically active intermediates. Angew Chem Int Ed 43:788824

Bunch AW (1998) Biotransformation of nitriles by rhodococci. Ant van Leeuwenhoek 74:89-97

Duthaler RO (1994) Recent developments in the stereoselective synthesis of $\alpha$-aminoacids. Tetrahedron 50:1539-1650

Gröger H (2001) Enzymatic routes to enantiomerically pure aromatic alpha-hydroxy carboxylic acids: a further example for the diversity of biocatalysis. Adv Synth Catal 343:547-558

Harper DB, Gibbs PA (1979) Identification of isobutyronitrile and isobutyraldoxime O-methyl ether as volatile microbial catabolites of valine. Biochem J 182:609-11

Håkansson K, Welander U, Mattiasson B (2005) Degradation of acetonitrile through a sequence of microbial reactors. Water Res 39:648-654

Kobayashi M, Shimizu S (1998) Metalloenzyme nitrile hydratase: structure, regulation and application to biotechnology. Nature Biotechnol 16:733-736

Kobayashi M, Shimizu S (2000) Nitrile hydrolases. Curr Opin Chem Biol 4:95-102

Layh N, Hirrlinger B, Stolz A, Knackmuss H-J (1997) Enrichment strategies for nitrile-hydrolysing bacteria. Appl Microbiol Biotechnol 47:668-674

Lowry OH, Rosebrough NJ, Farr AL, Randall RJ (1951) Protein measurement with Folin phenol reagent. J Biol Chem 193:265275

Marmur J (1961) A procedure for isolation of DNA from microorganisms. J Mol Biol 3:208-214

Marmur J, Doty P (1962) Determination of the base composition of deoxyribonucleic acid from microorganisms. J Mol Biol 5:109118

Mateo C, Fernandes B, van Rantwijk F, Stolz A, Sheldon RA (2006) Stabilisation of oxygen-labile nitrilases via co-aggregation with poly (ethyleneimine). J Mol Catal B Enzym 38:154-157

Mueller U, Huebner S (2003) Economic aspects of amino acids production. In: Faurie R, Thommel J (eds) Microbal production of L-amino acids. Springer, Berlin, pp 137-171

Navarro-Llorens JM, Drzyzga O, Perera J (2008) Genetic analysis of phenylacetic acid catabolism in Arthrobacter oxydans CECT386. Arch Microbiol 190:89-100

Pfennig N, Lippert KD (1966) Über das Vitamin $\mathrm{B}_{12}$-Bedürfnis phototropher Schwefelbakterien. Arch Microbiol 55:245-256

Ravichandran S, Dattagupta JK, Chakrabarti C (1998) D-Phenylglycine hydrochloride. Acta Crystallogr Sect C Cryst Struct Commun 54:499-501

Sorokin DYu, van Pelt S, Tourova TP, Muyzer G (2007a) Acetonitrile degradation under haloalkaline conditions by Natronocella acetinitrilica gen. nov. sp. nov. Microbiology 153:1157-1163

Sorokin DYu, van Pelt S, Tourova TP, Muyzer G (2007b) Microbial isobutyronitrile utilization at haloalkaline conditions. Appl Environ Microbiol 73:5574-5579

Van de Peer Y, De Wachter R (1994) TREECON for Windows: a software package for the construction and drawing of evolutionary trees for the Microsoft Windows environment. Comput Applic Biosci 10:569-570

Vetter J (2000) Plant cyanogenic glycosides. Toxicon 38:11-36

Weatherburn MV (1967) Phenol-hypochlorite reaction for determination of ammonia. Anal Chem 39:971-974 